УДК 613.26/.29

\title{
ПИТАННЯ ЯКОСТІ, НАТУРАЛЬНОСТІ І ТОКСИКОЛОГІї МОЛОЧНИХ ПРОДУКТІ
}

M.I. Сичов, кандидат хімічних наук, доцент кафедри якості та безпеки життя людини, E-mail:odiv@@mail.ru Оеска державна академія технічного регулювання та яюосі, м.Одеса, вул.Ковалььька, 15

Анотащія. Здійснено огляд літературних джерел щодо особливостей і харчової цінності, якості і безпеки молочних продукків. Наведено основні види та способй їнььї фальсифікаціі, провод номативних документів щодо технічних умов і ви-
вних джерел їньої токсккологічної небезпеки, стану законодавчих та нора мог до якості молочних продуктів в Україні та в інших краӥнах, існуючих лабораторних методів встановлення іх якості та безпеки. Розглянуто необхідність введення в нормативну документацію в Украйні нових методів аналізу для виявлення фа-
льсифікатів. Розгпянуто особлливості та переваги хроматографінних методів аналізу молочних пролуктів та можливість застосування більш простих і доступних засобів встановлення натуральності молочної продукшії.

Ключові слова: продукти молочні, фальсифікація, ідентифікація, натуральність, склад, безпечність, меламін, методи аналізу, хроматографія.

\section{ВОПРОСЫ КАЧЕСТВА, НАТУРАЛЬНОСТИ И ТОКСИКОЛОГИИ МОЛОЧНЫХ ПРОДУКТОВ}

М.И. Сычев, кандидат химических наук, доцент кафедры качества и безопасности жизни человека, E-mail:odiv@@mail.ru

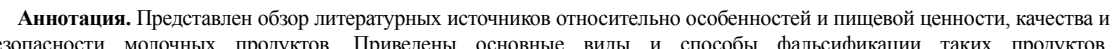
проанализированы источники токсикологической опасности фальсификатов, состояние законодательных и нормативных документов относительно технических условий и требований к качеству молочных продуктов в Украине и в других странах, существующих лабораторных методов установления их качества и безопасности; предлагается введение в нормативную документацию в Украине нових методов анализов для выявления фальсификатов и опасных веществ.
Рассмотрены особенности и преимушества хроматографических методов анализа молочных продуктов, возможности Рассмотрены особенности и преимущества хроматографических методов анализа молочных продуктов, возможности
применения более простых и доступшых способов химического анализа для установления натуральности молочной применения

Кродукции. меламин, методы анализа, хроматография.

Copyright $\odot 2015$ by author and the journal "Food Science and Technology"

This work is licensed under the Creative Con
http://creativecommons.org/licenses/by/4.0

(c) (i)

DOI:

Вступ

Ризики від споживання неякісної контрафактно харчової продукції найбільш суттеві не тільки для рентоспроможність на світовому ринку продукей українських виробників. Закон України «Про безпечність та якість харчових продуктів» [1] визначас відповідні вимоги при виробництві. Нові економічні відносини, що склалися в наш час, призвели до відкритості ринку, збільшення у сфері збуту фальсифікатів контрафактних харчових продуктів, серед яких провдне місце займають молочні продукти. За даним офіційної статистики фальсифікована продукція Європі складає $7 \%$, у Росії-12\%, Україна ж займас 10 місце у світі з випуску фальсифікованої продукції [2]. Фальсифікаторів не цікавлять інші мотиви, окрім фінансової вигоди, тому виробництво фальси-
фікатів завжди приносить прибуток. Найбільш небез- печною $є$ фальсифікація із заміною корисних властивостей, зміною натурального складу, введенням шкідливих для здоров'я людей компонентів. Саме такі види фальсифікації найбільш розповсюджені у виробництві молочних продуктів, які мають широкий асо. білше достпи м я вача. Методи фальсифікаїі завжди зводятья до порушень технотогї̈ виробництва за рахунок викорисрушень технологіі виробництва за рахунок викорис-
тання невідповідної сировини 3 наступним доведенням фізико-хімічних показників до встановлених стандартами норм. Як свідчить зарубіжний досвід вивчення фальсифікації молочних продуктів та вітчизняних аналогів, на практиці найбільш часто зустрічаються наступні способи якісної фальсифікації цих продуктів [3,4]
- використання немолочних видів сировини, частзаміна жиру коров'ячого молока на рослинні жири;

- фальсифікація натуральних молочних білків, часткова або повна заміна їх меламіном та соєвим білзастосування консервантів; - застосування харчових фарб (за винятком $\beta$ аротину ) ;

- застосування підсолоджувачів;

.ii i, згущеному молоці;

их речовин (соди,

Звичайно же ше не всі фальсифіковані продукти тотожні щодо їх негативного впливу на людину. Так загущення мукою, крохмалем, зниження кислотності содою ведуть до зниження харчової цінності та смаків. А от застосування консервантів, що не дозволені гігієнічними нормами - це вже загроза здоров’ю. Застосування аспартаму в якості підсолоджувала - це вже пряма загроза хворим на фенілкетонурію. Дуже небезпечним $є$ меламін в молоці, який додають для фальсифікованої компенсації вмісту білку. А щодо добавок рослинних жирів, або ж заміна ними натурального жиру молока, то більшість вчених, медиків, дослідників вплй таКк Жирів на людський організм схиляються до визнання негативних наслідків від їх вживання.

Постановка проблеми

Постановка проблеми в загальному вигляді полягає у розгляді видів фальсифікаціі молочних продуктів, вимог чинних нормативних документів щодо їньої якості та безпеки, огляд методів визначення якості та ідентифікаціі іхньоі натуральності, розроблення пропозиций для боротьби з контрафактною та небез





Мета статті: провести аналіз видів та способів фальсифікації молочних продуктів, положень законодавчих актів та чинних нормативних документів щодо якості та методів контролю шіеї продукшії, наланн рекомендашій щодо вдосконалення методів виявлення фальсифікатів, встановлення відповідності та натуральності у випадках:

застосування консервантів у вершках, сметані, згущеному молоці;

застосування нейтралізуючих речовин (соди, крейди, аміаку, інших).

застосування харчових фарб (за винятком $\beta$ каротину );

- застосування підсолоджувачів нції;

туральних молочних;
- застосування меламіну для надання виду наяв-

Літературний огля/

Молочні продукти мають чи не найбільший асортимент, відрізняючись по групах:

цільномолочна продукшія, в тому числі і частково знежирена або $з$ добавками (вітаміни, білок); кисломолочна: кефір, сметана, ряжанка, йогурти; масла на основі жирів молока;

уродукти переробки молока - сири, консерви. У лірі молока міститься добова норма жиру, ка作 та фосфору, що необхідні організму зрілоі лю2. 글

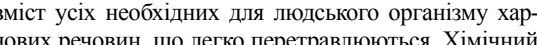
скал рови, Цо легко перетравлююоься. Хімічний


у . с до $3.3 \%$ і які містять всі незамінні амінокислоти. Молочний жир складається із складної суміші анитлицеридів, в яких насичених жирних кислот 60 $75 \%$, ненасичених - біля $30 \%$. Молочний жир містить також низьюомолекулярні насичені жирні кислоти: масляну, капронову, каприлову і капрінову (4$10 \%$ ), які обумовлюють специфічний смак молочного жиру. Ненасичені жирні кислоти (лінолева, ліноленова і арахідонова) при вмісті $3-5 \%$ надають молочному жиру легкоплавкість при $27-34{ }^{\circ} \mathrm{C}$, що ббумовлює його добре засвоєння. Основними вуглеводами молока є лактоза, моносахариди (глюкоза, галактоза та ін.). Мінеральних речовин в молоці міститья до 1\%, в іхньому складі 50 елементів, осноними 3 яких калій, натрій, кальцій, магний, фосфор, сульфур, хлор. Серед мікроелементів найбільш важ-

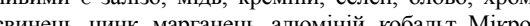
слементи забезенуют будову i ай важливих ферментів, вітамінів і гормонів, які необхідні для обміну речовин. Молоко містить ферменти, основні з яких редуктаза, пероксидаза, каталаза, фосфатаза, ліпаза та інші [5].

Незважаючи на властиві кожному продукту вимопи щодо якості і безпеки $є$ одна головна вимога - науральність, відсутність сировинних складових, не властивих природньому продукту тваринного походження. На молочні продукти існують відповідні нормаиввні документи, що містять органолептичні, фізико-хімічні та токсикологічні вимоги до продукту ДСТУ 2661.2010, ДСТУ 4274:2003; дСТУ 4399.2005 ДСТУ 4418: 2005; ДСТУ $4421: 2005$ ).

Появі та розповсюдженню контрафактної та сфальсифікованоі продукції сприяють прийняті на сьогодні методи досліджени пльки загальних властивос-

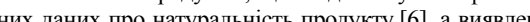


ня фальсифікатів можливе лише за результатами ідентифікації, фізико-хімічних аналізів, підчас довол складних. Процесу фальсифікації сприяе фактична відсутність дієвого контролю продукції, що реалізується, уповноваженими органами виконавчоі влади. Відсутні опитування споживачів, виведення рейтингу якості молочних продуктів, аналіз скарг громадян на факти реалізації неякісної продукції. Споживач довіряє рекламі, інформації на упаковці товару та власним смаковим уподобанням. Недостатньо і публічної інфікаті $\mathrm{c}$ сn ілентифіканії $i$ аналізів моточних прошугі ма татуральність існуе достатня їня кількість, вони мають різну ступінь склалності і різне призначення. Деякі методів достатньо прості і придатні для використання споживачами на побутовому рівні, наприклад встановлення вмісту муки або крохмалю йодною реакшією, вмісту соди або крейди оцтом, натуральності масла вершкового по смаку та плавкос

Складні методи потребують лабораторного обладнання і не можуть бути застосовані в умовах реалізації на ринках ветеринарними лабораторіями, що дають посвідчення про якість молочних продуктів. Повну ідентифікацію продуктів, що має за мету встановлення якості, проводять органи по оцінці відповідності та випробувальні лабораторії.

\section{Основна частина}

Основними методами визначення фальсифікатів Україні $\epsilon$ : інформаційний, органолептичний, фізикохімічний, хіміко-токсикологічний, радіологічний та мікробіологічний. Існує і ряд спеціальних досліджен щодо вмісту контамінантів та ксенобіотиків біологіного походження

У Російській Федерації з 2008 року діє Федеральний закон від 12.06.2008 № 88-Ф3 «Технический регламент на молоко и молочную продукцию». Для





- вмісту сухих речовин молока

- наявності і вмісту жирів немолочного походження та їх кількості;

вмісту білку і співвідношенню сивороточних білків і казеїну, наявність вмісту меламіну.

Важлива роль відводиться змісту споживчого маркування, складу продукту, його харчовій цінності та умовам безпеки

Згідно Технічного регламенту Республіки Казахстан «Требования к безопасности молока и молочно продукции» ідентифікація молока і молочної продукції проводиться для оцінки споживчої інформаціі, встановлення відповідності продуктів і наявності фальсифікатів по показниках: вміст сухих речовин, ная-

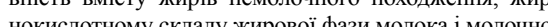
продукції [8].

Вважасться,що найбільш небезпечними серед ктів

консерванти (саліцилова, борна, сорбінова, бенна кислоти);

- рослинні жири, які частково або повністю заміщують молочні жири в сметані, вершках, згущеному

- штучне підвищення вмісту білку добавками соєпродуктів та меламіну.

Застосування рослинних жирів, в основному пабіль ро, продуктів [9-12]. Ці жири одержують з м'якоті або яер плогів тропіних масляних кульгур пресуван або екстракцією жирів органічними розчинниками. Тропічні жири здавна ор характерні доля харчування населення України, тому і виникають проблеми токсико - гігієнічного характеру при введені їх в наш раціон. Особливий негативний вплив ці жири мають на людей 3 хворобами шлунково-кишкового тракту та серцево-судинної системи. Необхідне глибоке вивчення впливу на організм людини транс-ізомерів жирних кислот тропічних жирів та залишкових кількостей екстрагентів. Тропічні жири піддають гідрогенізациї воднем для збільшення термінів зберігання, при цьому жирні кислоти переходять в форму трансізомерів. А такі транс-ізомери порушують ліпідний обмін орталізму лоди, вражол судини, викликаар при споживанні з раннього віку. Пальмовий жир займає другу позишію (31\%) веред ілших у світор завиробницвві, соняшникова олія - четверте місце $(9,14 \%)$.

У розвинутих країнах світу прийнято декларувати вміст транс-ізомерів в харчових продуктах. Враховуми рослинними жирами, в яких вміст транс-ізомерів досягае $49 \%$, необхідно проводити контроль за вмістом транс-ізомерів в масложирових продуктах на стадії державноі експертизи $і$ атестації виробництв, а також проводияи періодичний контроль іхньої продукції і об'ємів використання тропічних жирів. Так, за даними проведених досліджень експертами ДПГ «Укрметртестстандарт» із перевірених зразків масла вершкового тільки у $20 \%$ продукту не було вмісту росродукії рітизиянх виробників молом згушеного та сметани, Виявлені не тільн рослинні жири в таких продуктах, але й консерванти у виді сорбінової та бензойної кислот [12]. У даний час вміст транс-ізомерів жирних кислот нормуеться і передбачасться їх контроль в спрейдах згідно ДСТУ ISO 5508-2001. Закон України «Про молоко і молочні продукти» встановлює розмежування між молочними продуктами і продуктами, що вміщують замінники молочних складомаркуво щ і повинно повідомлятися в споживчому
Відносно меламіну і його застосування для іміта- $\quad$ рій, $\epsilon$ газохроматографічне визначення жирнокислотціі вмісту білку в молоці і молочних продуктах, то ця ного складу молочних продуктів і виявлення фальситема $\epsilon$ вкрай актуальноо щодо оцінки безпеки продуктів [14]. Увага до меламіну виникла в $2007-2008$ роках, після масового захворювання тварин внаслідок поїдання штучних кормів. Надалі стало відомо про забруднення меламіном в кількості до 2560 мг/кг різних видів харчових продуктів (молоко, сухе молоко,
дитячі молочні суміші, йогурти, цукерки, шоколад дитячі молочні суміші, йогурти, цукерки, шоколад,
напої) в Китаї і в ряді країн Південно-Східньої Азії.

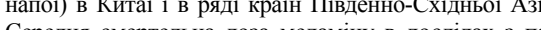
Середня смертельна доза меламіну в дослі,
цюками складала 3161 мг/кг маси тіла $\left(\mathrm{LD}_{50}\right)$.

Характерна дія меламіну на організм людини виражена перш за все в ураженні сечовидільної системи: випадіння кристалів в сечі 3 наступним утворен. льсифікації продуктів меламіном деякими фірмами в Китаї, причому меламін був добавлений в продукти харчування умисно. Посуд 3 меламіну 3 часом втрачас захисний шар полімеру і меламін переходить в їжу, тому посуд 3 меламіну заборонений на території Росії. Заборона Роспотребнагляду відноситься і до імпорту молоко 3 Китаюю [15-19].

Зрозуміло, наскільки актуальним $є$ питання організації і проведення випробувань щодо найбільш важливих та шкідливих для здоров'я людини показників складу, натура

Визначення масової частики жиру в молочних якості. В Україні прийнято бутирометричний мето визначення загального вмісту молочних жирів. В останні роки в ряді інших країн активно проводять науково-дослідні роботи, які направлені на пошук нових, більш експресивних методів визначення жирів [20]. При цьому використовують деякі властивості жирів:

здатність змінювати швидкість роз; здапість кульок жиру поглинаа запніь жинх кислот до люмінесценції під лазерного випромінювання;

здатність жиру змінювати теплопровідність молока ;

датність атомів водню в молекулах тригліцериді


аналізаторів

Найбільш прийнятним і започаткованим у всіх дослідженнях та у практищі випробувальних лабораторій методом визначення справжності та відповідності $\epsilon$ вивчення жирно-кислотного складу продуктів. Звичайно, що цей метод $\epsilon$ прерогативою оснащених лабораторій і випробувальних центрів. Таким, що викликає найбільшу увагу вчених і практиків лаборато-

Харчова наука і технологія
Вище вже було вказано [9], що саме жирнокислотний склад молочного жиру молока і продуктів знього є «відбитком нальців», що буде свідчини про справжність або ж фальсифікацію продуктів. Відміноми особливостями складу жирних кислот натур нного молочного жиру $\epsilon$

наявнісь масляноі кислот;

в (пентадеканової , (в

. олеїнової кислоти) - не більше 3-5\%

При оцінці результатів слід вважати на склад стеринової фракції, яка чітко залежить від природи жиру
: тваринного або рослинного походження. При вмісті виключно молочного жиру в стериновій фракції повинен бути тільки холестерин. У рослинних жирах він відсутній, але присутні інші стерини: брасикастерин, кампастерин, слитастерин, $\beta$ - стерин та інші.

Таким чином, оцінка фальсифікації жирової фази молочних продуктів встановлюеться за результатами метвяня одержаних співвідношень масових часток сильних естерів жирних кислот або іхніх сум з повченим [9]. Можна довоти, шо недолі г добре витографічного методу вважають його складність, особливість процесів пробопідготовки, вплив індивідуаиих характеристик приладів. $€$ дискусійним і граиячне значення вмісту тих чи інших кислот, торії алгоритми інтерпреташії аналітичних результатів. Слід відзначити, шо хроматографічний метод по ГОСТ Р54471-99 «Жир молочный. Метод обнаружения растительных жиров газожидкостной хроматографией стеринов», гармонізований 3 міжнародним стандартом ISO 3594 i прийнятий як основний в «Техническом регламенте на молоко и молочную продуметоду контролю [7].

Для практики роботи виробничих і рядових лабораторій $є$ більш придатним визначення числа Рейхарта-Мейсля, яке $є$ однією $з$ констант молочного жиру 1 характеризуе вміст в 5 г жиру низькомолекулярних водорозчинних летючих жирних кислот. Якщо для лля росли льмового - відповідно $6-9 ; 4-7 ; 0,1-1,5$ ). Також можливо застосувати ше одну константу - йодне чиспо. Вона характеризуе вміст ненасичених кислот в жирі і дає можливість відрізнити молочний жир від рослинного. В такому разі застосовують показник співвідношення йодного числа $\mathrm{i}$ числа Рейхартарослинних жирів від 90,8 (пальмове) до 754,2 (соняшникове) [20]. 2i 0,2 до 25 ( 
В Україні розроблено подібну методику, яка $є$ область визначення ще не введених в перелік чинною, що також заснована на визначенні числа обов'язкового визначення речовин - токсикантів. ІсРейхарта-Мейсля і застосовуеться для визначення ма- нуючі методи «відбитків пальців», - хо характерні для сової долі немолочих жирів в комбінованій жировій кожного молочного продукту 1 є доступними для фазі [24], яка може бути використана i для визначен- проведення аналізів та наступної ідентифікації, не ня фальсифікатів оочної продукції. Висновки ребують доповнення такими сучасними методами. Численні наукові дослідження, запропоновані хромаАналіз положень основних законодавчих і норма- тографічні методи аналізів та новітні прилади вітчизтивних актів України щодо якості молочних продуктів няних та зарубіжних аналогів не доведені до практине дозволяє зробити висновки про однозначність ви- - лю ї продукії̈, шо с вимогою часу та

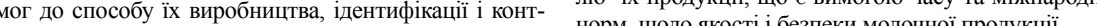
ролю якості та натуральносгі, наявності нормативних Виконання попереджувальних дій із застосув оложень щодо виявлення фальсифікатів даного виду вм поліл харчових продуктів стандартизованими методами нямеденяя моніторингу та статистики виявлення базьконтролю.

Контроль, що здійснюється органами сертифікацій продукції, мас явно недостатню кількість критеріїв робоси лабораторій контролюючих органів. Діюч державні стандарти України щодо якості і безпеки молочних продуктів містять тільки узагальнені показники і перелік методів аналізів, які не дають можли-
вості виявити денатуризовані, сурогатні, сфальсифіковані і контрафактні молочні продукти, розширити

Сиисок літератури:

безпечність та якість харчових продуктів» від 23.12.1977, №771/97 дР / Офішійний веб-портал Верховної Ради Україн. [Електронний ресурс].-- Режим доступу: htpp: //zakon2.rada.gov.ua / laws/ show/

Таврись, О.М. Аналіз методів виявлення фальсифікаиії продуктів харчування: теоретичний аспект товарознавства /О.М.Гаврись, А. С. «ральни

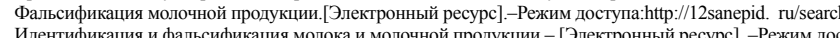

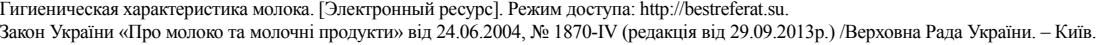
- [Електронний ресурс]- Режим доступу! http:///www.rada.gov.ua.

в

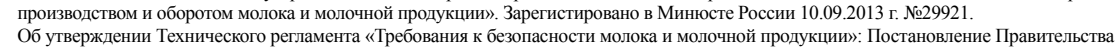

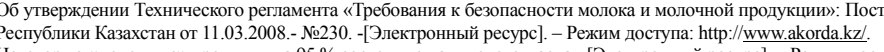

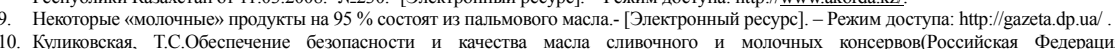
ТТ.СКуликовская, Т.Б.Гусева, О.М.Караньян, ТЕ.Маркевич // Федеральное агентство по государственним резервам.-[Электронный реcypc].-Режим доступа: http://rosreserv.ru/folder/l.

1. Пальмовое маслол: украинские традиции фальсификации продуктов.[Электронный ресурс].-Режим доступа: htpp://censor.net.ua

. Про затвердження Тернічного регламенту щодо правил маркуввння харчових продуктів. Наказ ДержспоживвстандартуУккраїи від

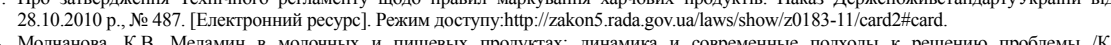
Молчанова, К.В. Меламин в молочных и пищевых продуктах: динамика и современные подходы к решению проблемы /К.
В.Молчанова, Е. Н.Фомина, А. Л.Носенко// Институт экогигиены и токсикологии им. Л.И. Медведя. [Электронный ресурс]. - Режим


6ww.mirnov.11.

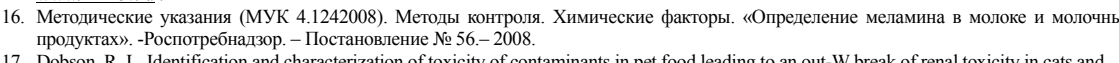

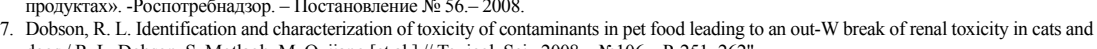
dogs / R. L. Dobson, S. Motlagh, M. Quijano [et al.]// Toxicol. Sci-2008. - No106. -P. 251-262"
18. Wong, S.N. The scare of melamine tainted milk products [Editoriall. / S.N. Wong. M. Chiu//Hong Kong J. Paediatr. (New Series) - 2008. №13, - P. 230- 234.

19. Turnipsed, S. Determination of melamine and cyanuric acid residues. / S. Turnipseed, C. Casey, C. Nochetto, D.N. Heller // Laboratory
information - October 2008. -Vol. 24. - bulletin № 4421 .

20. Лепилкина, О. В. Методы контроля содержания жира в молокосодержащих продуктах /О.В.Лепилкина, Тетерева Л. И. //Журнал

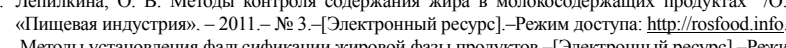

21. Методы установления фальсификации жировой фазы продуктов.-[Электронный ресурс]--Режим доступа: htpp:// test.org.ua.

Чмиленко, Ф. А., Установление фальсификации молочной продукции методами газовой хроматографии / Ф.А. Чмиленко, Н.П.
23. Нафталиев, С.И. Газохроматографическое определение жирнокислотного состава заменителей молочного жира и других соецияализированньх жиров / С.И.



\section{QUESTION OF QUALITY, NATURALNESS AND TOXICOLOGY OF DAIRIES}

M.I.Sichov, candidate of chemical sciences, associate rofessor of department of quality and safety of life man, $E$ -

Odesa state academy of the technical adjusting and quality, Odesa, Kuznechnaya str.,15

Annotation. In the article the review of literary sources iscarried out in relation to the features of food value, of qualityand safety of dairies, basic kinds over and methods of hef these, falsification, of the state oflegislation and normative documents in relation to technicalrequirements and requirements to quality of dairies inUkraine, existent laboratory methods of establishment oftheir quality and safety, examined necessity introduction fornormative documentation method analysis for establishmentnaturalness. Keywords : milk, dairy produce, falsification, identity, naturalness, composition, fat, safety, melamine, methods of analysis, romatography.

References
Zakon Ukrayiny Pro bezpechnist' ta yakist' kharchovykh produktiv vid 23.12.1977, №
Ukrayiny [Elekktronnyy resurs] Rezhym dostupu: htpp:// zakon2.rada.gov.ua / laws/ show

show dektiv kharchuvannya teoretychnyy aspect tovaroznavstva. Zb.nauk. pr. NTU ( harkivskyy politekhnichnyy instytut Kharkiv: NTU KhPI. 2012; 11: 8-14.

Fal'syfykatsyya molochnoy produktsyy [Elektronnyy resurs] Rezhym dostupa:hthp://12sanepid. ru/search.
Ydentyfykatsyya fal'syyykatsyya moloka y molochnoy produktsyy [Elektronnyy resurs] Rezhym dostup

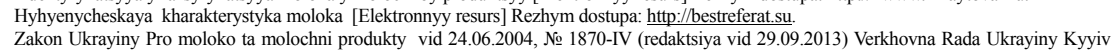

[Elektronnyy resurs] Rezhym dostupa: hittp://www.rada.gov.ua
Postanovlenye Hlavnoho hosudarstvennoho sanytarnoho vracha Rossyyskoy Federatsyy ot 9 yyulya $2013 \mathrm{~h}$. 33 O nadzore za proyzvodstvom y
oborotom moloka y molochnoy produktsyy. Zarehystyrovano v Mynyuste Rossyy 10.09 .2013 h. № 29921 . Ob utverzhdenyy Tekhnycheskoho rehlamenta Trebovanyya $\mathrm{k}$ bezopasannosty moloka y molochnoy produktsyy Postanovlenye Pravytel'stva
Respublyky Kazakhstan ot 11.03 .2008 №230 [Elektronnyy resurs] Rezhym dostupa: http://www.akorda.kzl.

. Nekotorie «molochnie» produkti na $95 \%$ sostoyat yz pal'movoho masla [Elektronnyy resurs] Rezhym dostupa: htpp://www.gazeta.dp.uad. Kulykovskaya T., Huseva T.,Karan'yan O, Markeychchc T, Federal'noe Obespechenye bezopasnosty y kachestva masla slyvochnoho y
molochnikh konservov (Rossyyskaya Federatsya). Federal'noe ahentstrvo po hosudarstvennym rezervam [Elektronnyy resurs] Rezhym dostupa:



13. Pro zatverdzhennnya Tekhnichnoho rehlamentu shchchodo pravyl markuvannyya kharchovykh produktiv. Nakaz Derzhspozhyyvstandartu Ukrayiny

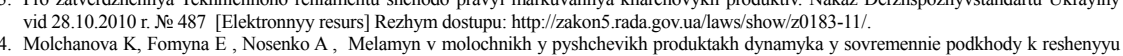
Mroblemy. Ynstytut ekohyhyen y toksykolohyy ym. L.Y.Medvedy [Elektronnyy resurs] Rezhym dostupa: hthp://www.medved.riev.ua.
prot.

16. Metodycheskye ukazanyya (MUK 4.1242008) Metody kontrolya Khymycheskye faktory Opredelenye melamyna v voloke y molochnykh
1. produktakh Rospotrebnadzor Postanovlenye № 56.200

Dobson R, Quijano Identification and characterization of toxicity of contaminnts in pet food leading to an outW break of renal toxicity in cats Wong S, Chiu M, The scare of melamine tainted milk products [Editorial]. Hong Kong J. Paediatr. (New Series). 2008; 13. 230-234 Turnipseed S, Casey C, Nochetto C, Heller D, Determination of melamine and cyanuric acid residues Laboratory information . October 2008;





produktsyy metodamy hazovoy Naftalyev S, Mel'nykova E, Selyvanova A, Hazokhromatohrafycheskoye opredelenye zhyrnokyslotnoho sostava zamenyteley molochnoho zhyra v druhykh spetsyalyzyrovannykh zhyrov. Sorbtsyonnye i khromatohrafycheskye protsessi. 2009; 9:574 - 581.

24. Metodyka vypolnenyya yzmerenyy massovoy doly nemolochnykh zhyrov $\mathrm{v}$ masle s kombynyrovannoy zhyrovoy fazoy: Svydetel'stvo o Отримано в редакцію 02.10 .2015
Прийнято до друку 22.11.2015 